the relation of it to the adaptability of certain soils and climates to the growth of the principal food crops.

Dr. Simon Flexner communicated the results of experimental epidemics produced in colonies of mice, in which it was shown that the mortality is enhanced by the introduction of fresh subjects after the epidemic has nearly run its course, the recurrence among the original colony seeming to be promoted by the disease of the new individuals.

Novel experiments on the skin temperature of pachyderms, reported by Dr. F. G. Benedict, embraced measurements of the temperatures of the elephant, rhinoceros, and hippopotamus at the New York Zoological Gardens. The difference between the results for these hairless animals and the results for man seem to depend largely on the great thickness of the skin, with accompanying control by outside as contrasted with interior temperature conditions.

A short popular account was given by Dr. C. G. Abbot of his experiments with solar cooking apparatus on Mount Wilson. The application of the solar heat is indirect through an oil circulatory apparatus, including a reservoir in which are inserted the ovens. All kinds of domestic cooking, except frying, and the preserving of fruits and vegetables were carried on. A jar of preserved pears prepared in the solar cooker was exhibited.

In a paper by J. R. Carson and J. J. Gilbert on transmission characteristics of the submarine cable, further employment was made of the extraordinary opportunity enjoyed by physicists during the war owing to the Government control of the Alaskan cable. A valuable paper had been given on the characteristics of this cable by signal corps officers at the academy meeting of 1920. Further applications of the results were now given.

\section{A New Treatment of Sleeping Sickness.}

$A^{T}$ a meeting of the Royal Society of Tropical Medicine and Hygiene held on May 2o, Dr. Claude H. Marshall, senior medical officer of the Uganda Protectorate, read a paper on a new treatment of trypanosomiasis (sleeping sickness) which had been originated by Dr. S. M. Vassallo, of the Uganda Medical Service, and himself. Remedies injected into the circulation, though they may sterilise the blood, probably do not destroy the parasites in the central nervous system, since the trypanosomes produce thickening and occlusion of the choroid plexus at an early stage of the disease, and thus prevent the passage of drugs from the circulation into the spinal fluid. In 19I8, therefore, in a well-marked case of sleeping sickness, an intravenous injection of neokharsivan was made, and three hours afterwards $2 \mathrm{oz}$. of the patient's blood was withdrawn; 20 minims of the serum was then injected into the spinal canal, and no further treatment was given; twentvseven months afterwards the patient was quite well, and his blood free from parasites. Of thirty cases similarly treated a large majority. were quite well at periods varying from six and a half to twentyseven months afterwards. The results are supposed to be due only in part to the drug contained in the serum; it is held that an antibody, trypanolysin, is formed in the blood of an infected patient, but that this cannot in ordinary circumstances reach the parasites in the central nervous system. Acting on this view, Dr. Vassallo is now treating cases along similar lines, but without previous intravenous injection of the drug. Later speakers emphasised the value of the work of Dr. Marshall and his colleague; but it was pointed out that it was early as yet to claim that the cases were permanently cured.

NO. 2695 , VOL. IO77

\section{University and Educational Intelligence.}

CAMBridge.-The Frank Smart prizes for botany and zoology have been awarded to A. J. Smith, Downing College, and G. S. Carter, Gonville and Caius College, respectively.

Glasgow.-Sir John H. Biles has intimated his intention to retire in September next from the John Elder chair of naval architecture and marine engineering, which he has held since r801. Prof. Biles has served in many capacities under the Admiralty and the Board of Trade, and is Consulting Naval Architect to the India Office. He received the thanks of the India Council for his services in designing and constructing river craft for the Mesopotamia Expeditionary Force during the war.

The late Mr. William J. Chrystal, chemical manufacturer, of Shawfield Works, Ruthèrglen, has bequeathed Io,oool. to the University, to be applied as the Senate may determine; and also ro,oool. to the Roval Technical College, for endowment.

Oxford.-Dr. E. Mallam, of Magdalen College, has been appointed Litchfield lecturer in medicine for two years as from October 5 next.

Final approval has been given in Convocation to the statute constituting the Delegacy for the Society of Oxford Home Students, and to the decree authorising the loan of 19 ,oool. from the special reserve fund for the completion of the Dyson Perrins Laboratory.

St. Andrews.-Dr. R. Robinson, director of research in the British Dyestuffs Corporation, Huddersfield, has been appointed professor of chemistry and director of the chemical research laboratory in succession to Prof. Irvine, now Principal of the University.

THE award of the William Gibson research scholarship for medical women (the second since its foundation) has been made by the council of the Royal Society of Medicine to Miss Gertrude M. A. Herzfeld, of Edinburgh.

The Chemical Age for June 18 announces that Mr. K. C. Browning, who for many years was Government analyst in Ceylon, has been appointed professor of chemistry and metallurgy at the Artillery College (formerly the Roval Ordnance College), Woolwich.

At the meeting of Leeds University Court, held on

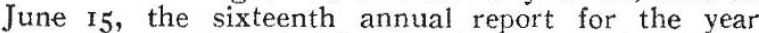
1919-20 was adopted. The vice-chancellor, Sir Michael Sadler, addressed the court, and stated that the most urgent question before the university was one of finance. The cost of maintenance was almost double that of $19 \mathrm{I} 8$, and the balance sheet for the current year would show a deficit of $14,000 l$. The present income was about $140,000 l$, of which 32.7 per cent. came from Government grants, 16.4 per cent. from local education authorities, 14.8 per cent. from endowments, etc., and 36.I per cent. from students' fees. At present the average cost per student is $75 l$. per annum, and the average fee paid is $27 l$. It has therefore been decided to adjust the fees to meet the difference between the total cost of the education provided and the funds derived from all other sources. Under present conditions this means an increase of $r o l$. per annum in the tuition fees and a small increase in examination fees. The report contains some account of the work in hand in the various departments, and concludes with a list of donations, etc., from which it appears that during the past year the university has received more than half a million sterling in donations, including eight gifts of ro,oool. and over, and one of $77,250 l$. , in addition to their annual subscription of 40ool. from the Clothworkers' Company of London. 